\title{
Rigid fixation of the lumbar spine alters the motion and mechanical stability at the adjacent segment level
}

\author{
Lomber omurgada rijit tespit komşu segment seviyesinde hareket ve mekanik stabiliteyi değiştirir
}

\author{
Ahmet KarakaşlI, M.D., ${ }^{1}$ Berivan Çeçen, Msc., ${ }^{2}$ Mehmet Erduran, M.D., ${ }^{1}$ Orçun Taylan, Msc., ${ }^{2}$ \\ Onur Hapa, M.D., ${ }^{1}$ Hasan Havıtcıoğlu, M.D., ${ }^{1,2}$ \\ 1Department of Biomechanics, Dokuz Eylül University, Health Sciences Institute, İzmir, Turkey \\ ${ }^{2}$ Department of Orthopedics and Traumatology, Medical Faculty of Dokuz Eylül University, İzmir, Turkey
}

\begin{abstract}
Objectives: This study aims to examine the motion and stability of the adjacent segment following rigid fixation of the lumbar spine.
\end{abstract}

Materials and methods: The study included 17 fresh-frozen lamb lumbar spines (including the sacrum to $\mathrm{T}_{12}$ ). Biomechanical testing was performed using an axial compression testing machine. Axial compression was applied to all the specimens using a loading speed of $5 \mathrm{~mm}$ min-1. A specifically designed fixture was used to generate torque $\leq 8400 \mathrm{Nmm}$. The fixture was used with each specimen to achieve flexion and extension, axial neutral compression, and right and left bending. All specimens were tested intact, and again after implantation using posterior pedicle screws and rod fixation. During testing intervertebral displacement at the adjacent level (L5-S1) was recorded continuously via extensometry.

Results: Axial compression and superior-inferior displacement were lower in the adjacent segment (L5-S1) than anterior-posterior displacement following rigid fixation. Statistical analysis showed that there was a numerical difference and a significant change between the intact spine and the adjacent segment in the axial compression and extension positions $(\mathrm{p}<0.027)$. The intact spines demonstrated the maximum displacement and the difference in extension positions were significant $(p<0.015)$.

Conclusion: Rigid fixation of the lumbar spine altered the range of motion at the adjacent segment level. As such, abnormal stress on the adjacent segment causes spinal instability, which may subsequently cause facet joint degeneration and low back pain.

Key words: Adjacent segment instability; facet joint; intervertebral disc; lumbar spine.
Amaç: Bu çalışmada lomber omurganın rijit tespitinden sonra komşu segmentin hareket genişliği ve stabilitesi araştirildi.

Gereç ve yöntemler: $\mathrm{Bu}$ çalışmada 17 taze donmuş kuzu lomber omurgası (sakrum $\mathrm{T}_{12}$ 'yi içeren) kullanıld1. Biyomekanik test aksiyel kompresyon test cihazı ile yapıldı. Aksiyel kompresyon tüm numunelere $5 \mathrm{~mm} / \mathrm{dk}$. yükleme hızı ile uygulandı. Özel dizayn edilmiş fikstür ile $8400 \mathrm{Nmm}$ tork oluşturuldu. Fikstür aksiyel yönde fleksiyon, ekstansiyon, sağ ve sola eğilme pozisyonlarında yüklenme uygulanacak şekilde numuneler ayarlandı. Tüm numuneler sağlam omurga, pedikül vida ve rod fiksasyonu sonrasında teste tabi tutuldu. Test esnasında komşu seviye L5-S1 arasındaki ayrılma değerleri süreğen bir şekilde ekstansometre ile kaydedildi.

Bulgular: Komşu segmentte (L5-S1), aksiyel yüklenme ve üst-alt ayrılma değerleri, ön-arka ayrılma değerlerinden düşük bulundu. İstatistiksel analizde sağlam omurga ile komşu segment arasında aksiyel kompresyon ve ekstansiyon pozisyonunda sayısal anlamlı değişiklikler tespit edildi $(\mathrm{p}<0.027)$. Bunun yanında ekstansiyon pozisyonunda komşu segmentte sağlam omurgaya göre daha yüksek çıktı $(\mathrm{p}<0.015)$.

Sonuç: Lomber omurganın rijit fiksasyonu komşu segment seviyesinde hareket genişliğini değiştirmektedir. Bundan dolay1, komşu segmentte anormal stres ve spinal instabiliteye neden olur; bu durum, faset eklem dejenerasyonuna ve bel ağrılarına yol açabilir.

Anahtar sözcükler: Komşu segment instabilitesi; faset eklem; omurlar arası disk; lomber omurga.

- Received: May 14, 2013 Accepted: November 21, 2013

- Correspondence: Berivan Çeçen, Msc. Dokuz Eylül Üniversitesi Tıp Fakültesi Ortopedi ve Travmatoloji Anabilim Dalı, 35210 Alsancak, İzmir, Turkey. Tel: +90 232 - 4123368 Fax: +90 232 - 2772277 e-mail: berivan.erik@deu.edu.tr 
Instrumented lumbar spine fusion which is a common surgical procedure is indicated in the treatment of degenerative disorders and lytic spondylolisthesis. ${ }^{[1-4]}$ The posterior structures of the facet joints are particularly important stabilizers of the motion segment. The orientation of the facets in the lumbar spine facilitates flexion and extension and aids in resisting torsion and shear load. ${ }^{[5]}$ Instability is usually restored with surgical fusion using pedicle screws and a cage, following decompression. Lumbar interbody fusion with supplemental posterior pedicle screw fixation is routinely used for the surgical treatment of painful spinal disorders. Posterior lumbar interbody fusion (PLIF) is a popular lumbar arthrodesis and posterolateral graft, and fixation can be easily added to PLIF to enhance spinal stability and to induce fusion. ${ }^{[6-11]}$

Alteration of the biomechanics at the junction of fused and mobile segments is thought to accelerate degeneration in adjacent motion segments. Adjacent segment disease has been reported to occur in as many as $35 \%$ of patients following spinal fusion. ${ }^{[3,6]}$ Initial positive results following posterior spinal fusion often degrade over time, as adjacent mobile segments proximal and distal to the fusion degenerate. ${ }^{[6]}$ Following arthrodesis at L4-L5, the most common level of fusion, adjacent disc disease additional surgery is required in approximately $15 \%$ of patients. ${ }^{[2,3,12]}$ Progression of the free mobile segment next to the spinal fusion is referred to as adjacent segment disease including disc degeneration, facet joint hypertrophy, spinal stenosis, and even acquired spondylolisthesis. ${ }^{[9]}$ The etiology of adjacent segment degeneration is not fully known, however, two theories have been proposed thus far. According to the first theory, in vitro research suggests that fusion increases intradiscal pressure (IDP) on the adjacent segment and that relative hypermobility is induced; both observations suggest that there is an increase in the load on the segment. The second theory posits that degeneration of the adjacent segment is indicative of the natural degenerative course of an aging disc. ${ }^{[3,7-9,13,1,14]}$

In this study, we aimed to investigate the mechanical behavior and instability of the adjacent segment following rigid fixation.

\section{MATERIALS AND METHODS}

This randomized study included 17 fresh-frozen lamb spines aged ranging between six to 12 months. The specimens did not have any macroscopically or radiologically observed diseases (Figure 1). The spine of each specimen was dissected from the sacrum to the $T_{12}$ level of the spine. All specimens were frozen and thawed immediately before testing. All specimens were potted with cement at the $\mathrm{T}_{12}$ vertebra and at the sacrum level. The specimens were tested twice; first as an intact spine and then following rigid fixation with an implanted rod and pedicle screws. Then, they were mounted for biomechanical testing. Biomechanical tests were performed using an axial compression testing machine (AG-I $10 \mathrm{kN}$, Shimadzu, Japanese), and two non-contact cameras (non-contact Video Extensometer DVE-101/201, Shimadzu, Japanese) obtained images of the gauge marks attached to the test specimens.

A specifically designed fixture was used to generate torque $\leq 8400 \mathrm{Nmm}$ through the axial movement of the actuator to achieve flexion and extension, axial compression, and right and left bending (Figure 2). ${ }^{[15]}$ Axial compression was applied in the axial position. First, the intact spines were tested. Then, transpedicular screws $(30 \times 4.5 \mathrm{~mm}$ mono axial titanium screws) were implanted into the L5, L4, and L3 vertebrae, and fixed with two rods $(6 \times 100 \mathrm{~mm}$ titanium) (Tipsan-Tibbi Aletler San. A.Ş.). During testing, intervertebral displacement at the L5-S1 level was recorded continuously using an extensometer. Gauge marks were applied to the test specimens with pins due to their sliding surface. Gauge marks were attached to L5 and S1 for measurement of superior-inferior and anterior-posterior displacement. Displacement values were recorded using a personal computer connected to the test machine and two noncontact cameras. Displacement data were evaluated using the Mann-Whitney U test and SPSS v.11.0 for Windows (SPPS Inc., Chicago, Illinois, USA).

\section{RESULTS}

Axial displacement findings are presented in Figure 3 and anterior-posterior displacement findings
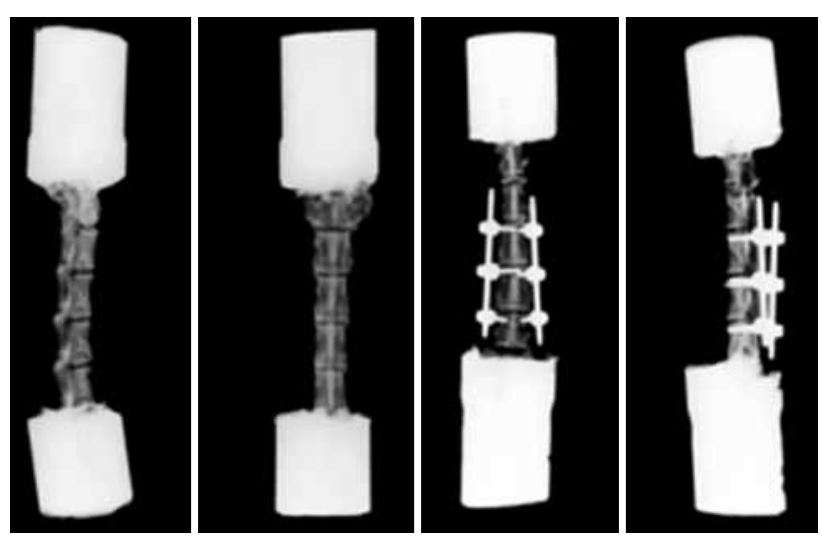

Figure 1. X-rays of intact spines and spines following rigid fixation. 


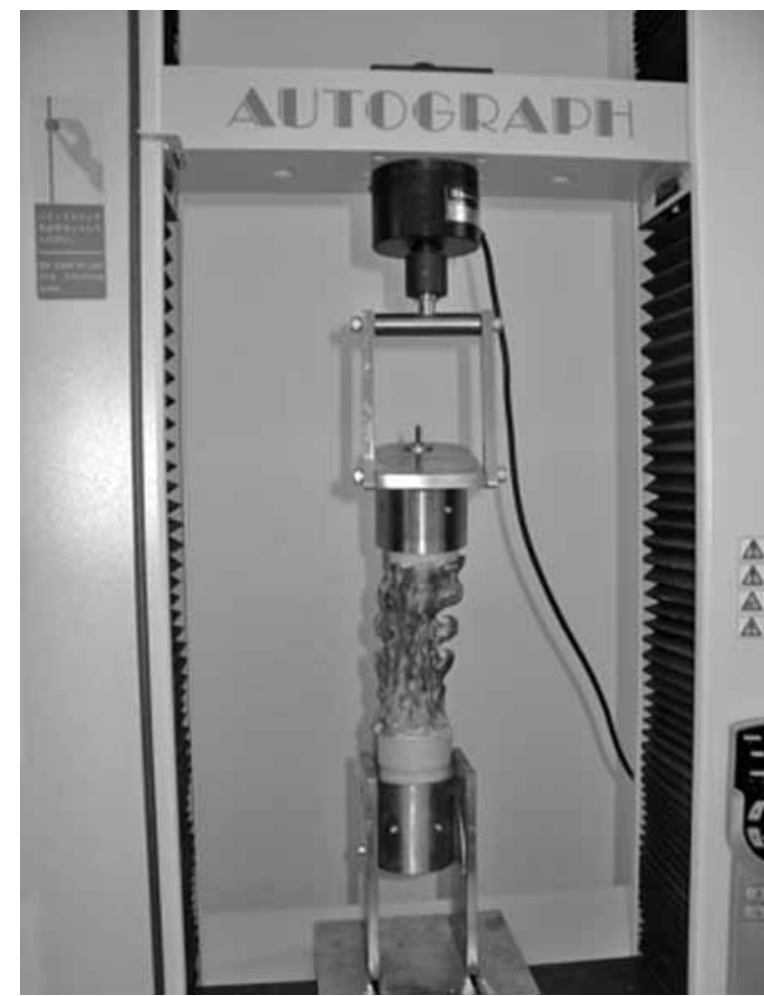

Figure 2. Moment testing (8400 $\mathrm{Nmm})$ of specimens in different positions; flexion-extension and right-left bending.

are shown in Figure 4. The rate of axial displacement in the axial plane was the highest in the intact spines (Table I). There was a significant difference in the axial compression position between the intact spines and the adjacent segments $(\mathrm{p}<0.027)$. The intact spines exhibited the highest displacement and the difference in extension was significant $(\mathrm{p}<0.015)$. The intact spines had the highest displacement in flexion, however, the difference between the intact spines and those with implanted rods was not significant. There was no significant difference in the left bending between the intact spines and those with implanted rods. The rate of anterior-posterior displacement of the adjacent segment was higher in the implanted spine than in the intact spine, while the adjacent segment exerted

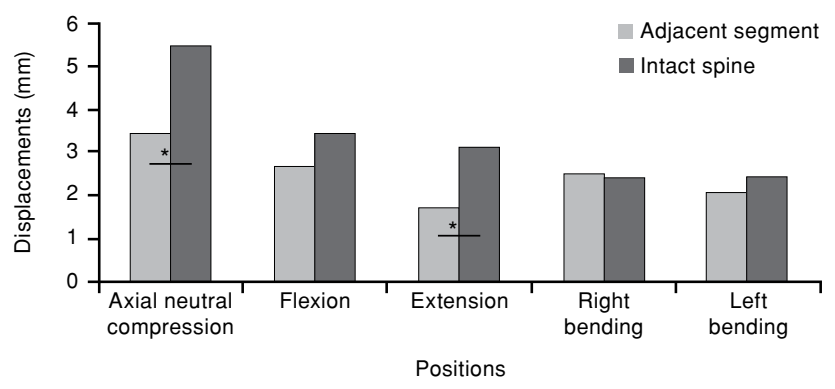

Figure 3. Neutral vertical displacement. higher displacement in flexion, however, it did not reach statistical significance. The findings show that there was no significant difference in the extension of the in the right and left bending positions between the adjacent segment and the intact spine.

\section{DISCUSSION}

Rigid instrumentation including pedicle screw systems is widely used with an increasing popularity thanks to its higher initial stability and fusion rates, low need for external immobilization, and earlier return to work than other methods. ${ }^{[3,6,8,9,12,16,17]}$ Although recent biomechanical studies have shown that a number of spinal devices can be used for rigid fixation and fusion at the treated level, little attention has been focused on the adjacent segment instability. $[2,5,6,8,12,13,16-18]$

The present study focused on the adjacent segment instability. As adjacent segment mobility increased, the anterior and posterior structures maintained stability and prevented instability. In the present lamb spinal model, displacement in intact spines was $1.12 \mathrm{~mm}$ in flexion and $3.83 \mathrm{~mm}$ in extension, versus $1.41 \mathrm{~mm}$ in flexion and $4.07 \mathrm{~mm}$ in extension following rigid fixation. In a porcine model, Tai et al. ${ }^{[2]}$ reported that displacement in intact spines in flexion and extension was $1.03 \mathrm{~mm}$ and $0.90 \mathrm{~mm}$, respectively, versus be $1.57 \mathrm{~mm}$ and $0.98 \mathrm{~mm}$, respectively, following spinal laminectomy.

Several studies measured IDP or laminar strain in adjacent segments following rigid fixation and fusion and evaluated indirectly load transmission through both the anterior and posterior spinal columns. The authors reported that IDP increased to some degree in adjacent segments in all directions, except extension. ${ }^{[14]}$ The total lumbar motion differed in a patient who had undergone fusion. In the present study, the range of motion (ROM) was $69 \%$ lower in flexion-extension, $73 \%$ lower in bending, and $34 \%$ lower in axial rotation in the spines implanted with rods than in the intact spines. ${ }^{[1,3,7,8,14,19,20]}$

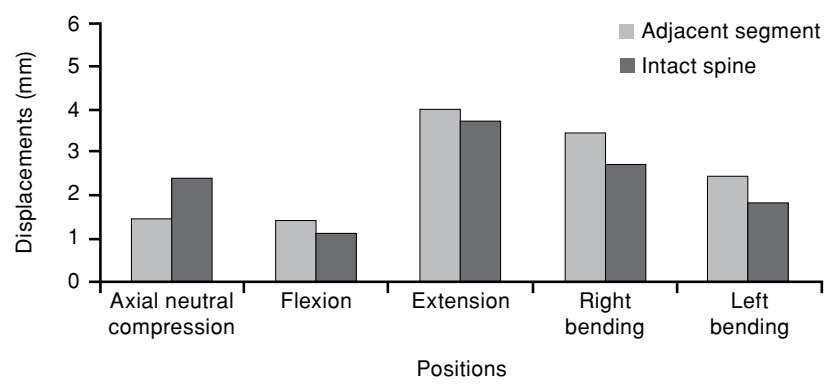

Figure 4. Transverse displacement. 
TABLE I

Displacement in each position

\begin{tabular}{|c|c|c|c|c|}
\hline & \multicolumn{2}{|c|}{ Superior inferior } & \multicolumn{2}{|c|}{ Anterior posterior } \\
\hline & Intact spine & $\begin{array}{l}\text { Spine with implanted rods } \\
\text { adjacent segment }\end{array}$ & Intact spine & $\begin{array}{l}\text { Spine with implanted rods } \\
\text { adjacent segment }\end{array}$ \\
\hline & Displacement (mm) & Displacement (mm) & Displacement (mm) & Displacement (mm) \\
\hline Axial neutral compression & 5.46 & 3.43 & 2.42 & 1.46 \\
\hline Right bending & 2.40 & 2.50 & 2.77 & 3.51 \\
\hline Left bending & 2.41 & 2.05 & 1.85 & 2.46 \\
\hline Flexion & 3.41 & 2.67 & 1.12 & 1.41 \\
\hline Extension & 3.12 & 1.71 & 3.83 & 4.07 \\
\hline
\end{tabular}

Rigid fixation and fusion of the mobile segment alter the biomechanics and kinematics of the entire lumbar spine. ${ }^{[1,3,6,9,14,17,20]}$ The precise relationship between the local stiffness produced by segmental fixation and accelerated degeneration, however, remains unclear. ${ }^{[1,9,21]}$

In the present study, there was significant variation between the intact spine and the adjacent segment in the axial position. The rate of displacement was higher in the axial position in the intact spines than in those following rigid fixation. Additionally, the rate of displacement in extension was significantly higher in the intact spines. The present study's testing protocol ${ }^{[2]}$ constantly tested the intact spines following rigid fixation of the L5, L4, and L3 vertebrae. Moreover, adjacent segment displacement and instability were analyzed under axial compression in both the intact spines and those following rigid fixation. The findings indicated that there was a significant difference in axial compression displacement in the adjacent segment and the intact spine $(p<0.027)$. Furthermore, there was a significant difference in superior-inferior displacement in extension between the adjacent segment and the intact spine.

Dynamic fixation can reduce facet joint force at the level of fixation, however, cannot significantly reduce the disc load. ${ }^{[21]}$ The maintenance of stability of the lumbar spine during movements, therefore, requires the coordinated movements of multiple motion segments. ${ }^{[22]}$ In the present study, the rate of anteriorposterior displacement in all positions was higher at the adjacent segment level than in the intact spine, indicating anterior-posterior instability at the adjacent segment level. Following rigid fixation of the spine, the adjacent segment of the facet joint was overloaded compared to the intact spine. On the other hand, the limitation to this study was that the bone mineral density of the spines was not measured before testing. Another limitation was that the specimens did not contain any living tissue, as the study was designed ex vivo.

\section{Conclusion}

The rate of anterior-posterior displacement of the lumbar spine following rigid fixation was significantly higher at the adjacent segment level than in the intact lumbar spine. The rate of anteriorposterior displacement in the implanted spine was higher than intact spine in all positions, except the axial position. There was a significant difference in between the intact spines and those with implanted rods in axial compression and extension. Moreover, abnormal stress on the adjacent segment may have caused spinal instability. Following rigid fixation, anterior-posterior instability at the adjacent segment level was observed. In conclusion, an increase in strain in the adjacent segment facet joint and disc may result in facet joint degeneration and low back pain. An understanding of the change in instability in the adjacent segment level and preventing facet joint hyper mobility should aid the development of new dynamic implant designs and the prevention of adjacent segment disease.

\section{Declaration of conflicting interests}

The authors declared no conflicts of interest with respect to the authorship and/or publication of this article.

\section{Funding}

The authors received no financial support for the research and/or authorship of this article.

\section{REFERENCES}

1. Hongo M, Gay RE, Zhao KD, Ilharreborde B, Huddleston PM, Berglund LJ, et al. Junction kinematics between proximal mobile and distal fused lumbar segments: biomechanical analysis of pedicle and hook constructs. Spine J 2009;9:846-53. 
2. Tai CL, Hsieh PH, Chen WP, Chen LH, Chen WJ, Lai PL. Biomechanical comparison of lumbar spine instability between laminectomy and bilateral laminotomy for spinal stenosis syndrome - an experimental study in porcine model. BMC Musculoskelet Disord 2008;9:84.

3. Yu CH, Lee JE, Yang JJ, Chang BS, Lee CK. Adjacent Segment Degeneration after Single-Level PLIF: Comparison between Spondylolytic Spondylolisthesis, Degenerative Spondylolisthesis and Spinal Stenosis. Asian Spine J 2011;5:82-90.

4. Derinçek A, Türker M, Cinar M, Cetik O, Kalaycioğlu B. Revision of the failed pedicle screw in osteoporotic lumbar spine: biomechanical comparison of kyphoplasty versus transpedicular polymethylmethacrylate augmentation. Eklem Hastalik Cerrahisi 2012;23:106-10.

5. Kaito T, Hosono N, Mukai Y, Makino T, Fuji T, Yonenobu K. Induction of early degeneration of the adjacent segment after posterior lumbar interbody fusion by excessive distraction of lumbar disc space. J Neurosurg Spine 2010;12:671-9.

6. Axelsson P, Johnsson R, Strömqvist B. Adjacent segment hypermobility after lumbar spine fusion: no association with progressive degeneration of the segment 5 years after surgery. Acta Orthop 2007;78:834-9.

7. Phillips FM, Tzermiadianos MN, Voronov LI, Havey RM, Carandang G, Renner SM, et al. Effect of the Total Facet Arthroplasty System after complete laminectomyfacetectomy on the biomechanics of implanted and adjacent segments. Spine J 2009;9:96-102.

8. Schulte TL, Leistra F, Bullmann V, Osada N, Vieth V, Marquardt B, et al. Disc height reduction in adjacent segments and clinical outcome 10 years after lumbar 360 degrees fusion. Eur Spine J 2007;16:2152-8.

9. Siewe J, Otto C, Knoell P, Koriller M, Stein G, Kaulhausen $\mathrm{T}$, et al. Comparison of standard fusion with a "topping off" system in lumbar spine surgery: a protocol for a randomized controlled trial. BMC Musculoskelet Disord 2011;12:239.

10. Oto M, Shah SA, Mohammed MA, Rogers KJ, Yorgova P, Holmes L. Effectiveness and safety of posterior titanium instrumentation in children with adolescent idiopathic scoliosis: a prospective study. Eklem Hastalik Cerrahisi 2011;22:124-8.

11. Demirçay E, Civelek E, Demiralay E. Solitary spinous process metastasis: a case report. Eklem Hastalik Cerrahisi
2013;24:58-61.

12. Ekman P, Möller H, Shalabi A, Yu YX, Hedlund R. A prospective randomised study on the long-term effect of lumbar fusion on adjacent disc degeneration. Eur Spine J 2009;18:1175-86.

13. Cho KS, Kang SG, Yoo DS, Huh PW, Kim DS, Lee SB. Risk factors and surgical treatment for symptomatic adjacent segment degeneration after lumbar spine fusion. J Korean Neurosurg Soc 2009;46:425-30.

14. Sim HB, Murovic JA, Cho BY, Lim TJ, Park J. Biomechanical comparison of single-level posterior versus transforaminal lumbar interbody fusions with bilateral pedicle screw fixation: segmental stability and the effects on adjacent motion segments. J Neurosurg Spine 2010;12:700-8.

15. Karakaşlı A, Yıldız DV, Kumtepe E, Kızmazoğlu C, Havitçığlu H. Biomechanical comparison of intact lumbar lamb spine and endoscopic discectomized lamb spine. Eklem Hastalik Cerrahisi 2013;24:33-8.

16. Choi Y, Kim K, So K. Adjacent segment instability after treatment with a Graf ligament at minimum 8 years' followup. Clin Orthop Relat Res 2009;467:1740-6.

17. Cheh G, Bridwell KH, Lenke LG, Buchowski JM, Daubs MD, Kim Y, et al. Adjacent segment disease followinglumbar/ thoracolumbar fusion with pedicle screw instrumentation: a minimum 5-year follow-up. Spine (Phila Pa 1976) 2007;32:2253-7.

18. Hoogendoorn RJ, Helder MN, Wuisman PI, Bank RA, Everts VE, Smit TH. Adjacent segment degeneration: observations in a goat spinal fusion study. Spine (Phila Pa 1976) 2008;33:1337-43.

19. Zander T, Rohlmann A, Burra NK, Bergmann G. Effect of a posterior dynamic implant adjacent to a rigid spinal fixator. Clin Biomech (Bristol, Avon) 2006;21:767-74.

20. Cakir B, Carazzo C, Schmidt R, Mattes T, Reichel H, Käfer $\mathrm{W}$. Adjacent segment mobility after rigid and semirigid instrumentation of the lumbar spine. Spine (Phila Pa 1976) 2009;34:1287-91.

21. Xu HZ, Wang XY, Chi YL, Zhu QA, Lin Y, Huang QS, et al. Biomechanical evaluation of a dynamic pedicle screw fixation device. Clin Biomech (Bristol, Avon) 2006;21:330-6.

22. Niemeyer TK, Koriller M, Claes L, Kettler A, Werner K, Wilke HJ. In vitro study of biomechanical behavior of anterior and transforaminal lumbar interbody instrumentation techniques. Neurosurgery 2006;59:1271-6. 